\title{
EVALUATION OF THE RELATIONSHIP BETWEEN YOUTH ENTREPRENEURSHIP AND EMIGRATION INTENTIONS: THEORETICAL-METHODOLOGICAL ASPECTS
}

\author{
Aurelija PETRONYTE் $\left(\mathbb{D}\right.$, Aurelija ULBINAITE் ${ }^{*}$ \\ Business Department, Faculty of Economics and Business Administration, Vilnius University, \\ Sauletekio al. 9, LT-10222, Vilnius, Lithuania \\ *E-mail: aurelija.ulbinaite@ef.vu.lt
}

\begin{abstract}
Purpose - the purpose of this article is to investigate the relationship between youth entrepreneurship and emigration attitudes by presenting a method for evaluating the link between youth participation in entrepreneurship promotion initiatives, entrepreneurship and emigration attitudes, and also to check its validity.
\end{abstract}

Research methodology - the quantitative test method presented in the article consists of 3 key parts that have their own specifics of evaluation and different methodologies.

Findings - the results of the study did not show the correlation between the analyzed elements.

Research limitations - although a method test made it possible to verify its suitability, a more representative sample of respondents is needed to provide valid results about the correlation of above mentioned 3 elements.

Practical implications - based on the methodology evaluated, everyone familiar with the material will be able to initiate surveys and/or scientifically based researches at a different territorial level on youth entrepreneurship and emigration intentions and to evaluate the extent of the youth involvement in entrepreneurship promotion initiatives and its relationship with the entrepreneurial spirit of the individual.

Originality/Value - this study contributed to the existing research on entrepreneurship, supplementing it with new insights on the existence of a relation between entrepreneurship promotion, entrepreneurship, and the tendency to emigrate, which, as far as the authors are aware, was researched neither in Lithuania nor globally.

Keywords: youth, entrepreneurship, emigration intentions, correlation, entrepreneurship promotion, employment.

JEL Classification: L26, F22.

Conference topic: Contemporary Issues in Economics Engineering.

\section{Introduction}

Youth unemployment, "brain drain", labour migration and the exclusion of disadvantaged - unemployed and not studying youth are among the major economic and social challenges of this decade for the many EU Member States, including Lithuania. Although migration offers young people opportunities for personal growth, development, education, employment, and career start-ups, family life, high emigration flows threaten the economic and social development and stability of the sending country. Large emigration rates, in the long run, can cause various problems for the state, i.e.: staff deficiency, health care, education funding, and other problems. Emigration influences the decline in population, marriage and birth rates, it causes the loss of working age people, youth, and this leads to ageing of society (van Mol, 2016).

According to data provided by the Science and Studies Monitoring and Analysis Center [MOSTA], the main characteristic of emigrants from Lithuania is that they did not work and did not learn before leaving $(75 \%$ of all emigrants). Of all age groups, most often young people aged 16-29 are leaving the country, accounting for about half of all emigrants each year (MOSTA, n.d.). According to the statistics of the Employment Service - "Užimtumo tarnyba", in 2017, average annual unemployment of young people aged 16-29 in Lithuania reached $8.6 \%$ and was the lowest in the period of 2011-2017 (Užimtumo tarnyba, n.d.), however, according to the data of Lithuanian Department of Statistics, in 2017 there was the largest emigration of young people (23.9 thousand) during the mentioned period (Lithuanian Department of Statistics, n.d.). According to Pocius and Burneika (2017), unemployment is a major feature of problematic regions, the consequence of which is not only economic well-being but also poverty, other socio- 
demographic problems, one of which is a problem of population decline and emigration, which, for years, has not lost its relevance.

Governments and international organizations are increasingly recognizing that as young people feel anxious about being in the labour market (career opportunities, salary levels, professional development, etc.), entrepreneurship promotion is becoming an important strategy for youth integration into the labour market, thus addressing employment challenges and emigration that is often provoked by these challenges. As announced by The Organisation for Economic Co-operation and Development [OECD] (2017), youth entrepreneurship is not a panacea that can solve the problem of unemployment, often referred to as the main cause of youth emigration, but it may be part of a policy response.

In 2016 the Government of the Republic of Lithuania acknowledged, that despite the growing economy and better situation in the labour market (lower unemployment rate), emigration remains a problem. Understanding the importance of the emigration issue, the Government presented a measures plan to reduce emigration and increase return migration. In the plan of measures, the primary focus is on promoting entrepreneurship - improving the conditions for business development, reducing administrative burdens, etc. In 2018 youth organizations also presented their position by saying, that self-realization and interesting work is very important for young people and it is important to create conditions to prevent emigration, so that young people do not want to leave their country of origin - entrepreneurship among young people should be promoted, more attention should be paid to housing for young people and families, the creation of a favourable business environment and the provision of decent jobs. Thus, the actualization of entrepreneurship at the political level suggests, that the promotion of entrepreneurship is expected to have a positive impact on the level of entrepreneurship, and it is believed, that more entrepreneurial people tend to create businesses, innovate and thus - contribute to the reduction of emigration by creating jobs for themselves and those around them, raise the economic level, country attractiveness, etc. Hence, based on the above-mentioned information the relevance of the topic can be based on 3 aspects:

1) The orientation and empowerment of youth entrepreneurship is not only a necessity but is always a relevant and significant topic for any country. In Lithuania, having noticed that youth emigration rates correlate with the unemployment rate (when unemployment is rising, emigration is increasing), entrepreneurship has been seen as one of the ways that can boost employment and reduce international migration. This is highlighted in the Government's Emigration Reduction Plan for 2016, the Demographic, Migration and Integration Strategy for 2018-2030, and the speeches of various policy figures. Identifying the effectiveness, efficiency, and impact of ongoing and implemented institutional programs, formal and non-formal education, promoting youth entrepreneurship, is an important part of the strategic management cycle. Based on the results of such evaluations, decisions can be made at the local or national level on the development of ongoing initiatives and their continuing relevance. However, in Lithuania, unlike in the world (Lorz, 2011), no research has been carried out to find out whether the promotion of entrepreneurship affects a person's entrepreneurship, or whether there is a link between entrepreneurship and emigration - perhaps more entrepreneurial people tend to prefer emigration. The latter assumption is based on the prioritization of entrepreneurship promotion in the context of measures to reduce emigration;

2) The monitoring data of the scientific research project The Global Entrepreneurship Monitor (2012), pointed out that it is likely, that more entrepreneurial people are more willing to migrate. It is based on the results of a survey, conducted in 69 countries, showing that the entrepreneurship of immigrants is higher than that of the locals, thus it is likely that entrepreneurial people are more likely to migrate. Therefore, there is a reason to believe that there is a correlation between the promotion of entrepreneurship, entrepreneurship, and the emigration intentions, which, to the authors' knowledge, has been studied neither in Lithuania nor globally;

3) The importance of studying the relationship between entrepreneurship and emigration is beyond the scientific novelty of the topic, complementing existing research in the field of entrepreneurship with new observations, but the results also show the tendencies of entrepreneurship and emigration attitudes of one of the most sensitive groups in society - those at risk of social exclusion and unemployed young people in one of the most depressed regions of Lithuania with youth decline and unemployment problems. Knowing these trends will allow us to decide on the entrepreneurship of young people - the motivation to create a business and to predict the potential extent of emigration.

Youth entrepreneurship and it's promotion in Lithuania has been studied quite extensively: Župerka and Župerkienè (2014) conducted a study on student entrepreneurship education in western Lithuania; Saulenas (2007) analyzed the situation of rural youth entrepreneurship and sought to identify the most effective promotion measures; Čiburienè and Guščinskienè (2009) carried out a study aimed at clarifying young people's attitudes towards entrepreneurship and their inherent qualities as entrepreneurs; Atkočiūnienè and Navasaitienè (2013) analyzed the role of rural communities in promoting youth entrepreneurship; various authors wrote about entrepreneurship education in educational institutions, assessed teachers' attitudes towards entrepreneurship education tools and the concept of teachers about entrepreneurship and entrepreneurship education. The topic of youth entrepreneurship has also received considerable attention internationally: Wiger, Chapman, Baxter, and DeJaghere (2015) noticed that while some of the entrepreneurship promotion programmes potentially are useful, they are an insufficient strategy for sustained entrepreneurship improvement, based on that, researchers presented a model of the factors affiliated with the effectiveness of youth entrepreneurship training; Samuel, Ernest and Awuah (2013) were assessing entrepreneurship intentions among marketing students in the Sunyani Technical University (Gana, Africa) using the same - 
Entrepreneurial Intentions Questionnaire [EIQ] that authors use in this work; some researchers investigated how school-age education affects entrepreneurial intentions (Falck, Gold, \& Heblich, 2017), others tried to identify the main challenges and prospects of youth entrepreneurship development in rural (O. G. Boateng, A. A. Boateng, \& Bampoe, 2014; Ngorora \& Mago, 2013, etc.) also in urban areas (Di Nunzio, 2015; Regele \& Neck, 2012, etc.). Some of the works of scientists have been actively used for writing this work, mentioning several: (Lorz, 2011; Salilew, 2017; Ferreira, Finisterra do Paco, Raposo, Rodrigues, \& Dinis, 2011; Salilew, 2017, etc.)

Research on emigration attitudes in Lithuania has received considerable attention both in the context of youth and in general in the context of society. In terms of research on youth emigration attitudes, the works of the following scientists should be mentioned: Merkys, Baršauskienè, and Antienè (2006) assessed the emigration attitudes of Lithuanian students and the factors determining them; Aidis and Krupickaite (2007) conducted a study on youth emigration, during which he studied the emigration attitudes of Lithuanian university students; Skačkauskaite (2007) studied international Lithuanian migration, student attitudes, approaches, and assessed emigration opportunities; Tiškutė and Sondaite (2011) performed a qualitative analysis of social and psychological factors causing the students' intention to emigrate, etc. Youth emigration intentions are also widely analyzed in the international context: (DakoGyeke, 2016) explored the migration intentions of Ghanaian youth and conducted a qualitative study to find out what motives motivate young people to emigrate; Roman and Vasilescu (2016) as well aimed to determine the factors that influence the decision of youth to migrate (Romanian youth case), one of the research results was that discrimination and the entrepreneurial behaviour were key factors that influenced the migration intentions of young adults, etc. There are even more authors who analyzed youth emigration, mentioning some of the newest: (Chuvashov, 2014; van Mol, 2016; Dibeh, Fakih, \& Marrouch, 2018; Salamonska \& Czeranowska, 2018; Traikova, Mollers, \& Petrick, 2018; Bastianon, 2019; Bakina, Yaremtchuk, Orlova, \& Krasnoperova, 2019; Herz, Diaz-Chorne, Diaz-Catalan, Altissimo, \& Carignani, 2019, etc.).

The object of the article - the relation between youth entrepreneurship and emigration attitudes.

The problem of the article - is there a link between youth entrepreneurship and emigration?

The aim of the article - after analyzing the theoretical aspects of entrepreneurship, to present a method for evaluating the link between youth participation in entrepreneurship promotion initiatives and entrepreneurship and emigration attitudes.

The methods applied in the article. The method of analysis of scientific literature was used in the article in order to analyze the concept of entrepreneurship, assessment methods, and promotion measures. The quantitative research method was used - questionnaire survey, statistical analysis of results obtained using Excel and SPSS 22 software package.

\section{Entrepreneurship and theoretical aspects of its assessment}

Entrepreneurship is now widely recognized as a driving force for sustainable economic growth, as entrepreneurs create new businesses, stimulate and shape innovation, accelerate structural changes in the economy, introduce new competition, and thus contribute to productivity growth (OECD, 2017). The abundance of analyzed sources justifies the fact that entrepreneurship is a dynamic and rapidly growing field of research with a long-standing intellectual tradition. Its intellectual roots are associated with the works of the scientists: R. Cantillon (1680-1734), F. Knight (1885-1972), J. Schumpeter (1883-1950) and others, which laid the foundations for the definition of entrepreneurship and revealed its relationship with innovation, economic growth, risk and uncertainty (Brown \& Thornton, 2013; Boutillier, 2014; Pekkala Kerr, Kerr, \& Xu, 2017; Chandra, 2018). Thus, the term "entrepreneurship" has played an important role in the academic literature for about 250 years and has become a centre of great interest in research over the last three decades.

The first sources defined entrepreneurship as a self-employed activity, where a person risks buying goods or services at certain prices and selling them at different prices (Chen \& Linan, 2009; Boutillier, 2014). It is also worth mentioning that since the introduction of this term to this day, the link to risk has remained quite strong. For example, in business vocabulary, entrepreneurship is defined as the tendency and the ability of people to engage in economic activity by combining capital, work and other economic resources to gain profit and assume all the risks associated with it (Ekonomikos terminų žodynas, n.d.). The European Commission defines entrepreneurship as an individual's ability to turn ideas into reality. This includes creativity, innovation, risk, the ability to plan and manage projects to achieve goals (European Commission, n.d.). Despite these and many other definitions of authors that emphasize the inseparability of entrepreneurship from the risk, J. Say pointed out that entrepreneurship is risky only when enterprises "violate the original - well-known rules", but it is not risky when acting systematically, purposefully and under control (Innovation and Entrepreneurship, n.d.).

Later (in the 19th and 20th centuries), analysts focused their research on the traits and personal qualities of entrepreneurs in order to understand and explain entrepreneurship. Scientists of that time (J. Say (1842-1924); A. Marshall (1842-1924) etc.) believed that the success of entrepreneurship depends on the qualities that every business person must have: the ability to determine the nature of the activity and its necessity in the market, the evaluation of efficiency, rationality and reliability, perseverance, adaptation to changing environmental factors 
(Boutillier, 2014; Chandra, 2018). About the middle of the 20th century, J. Schumpeter drew attention to the relationship between entrepreneurship and innovation and emphasized the importance of innovative entrepreneurs as a key tool for the economy to move from a static balance based on individual innovation and entrepreneurial skills (Braguinsky \& Klepper, 2009). Thus, the entrepreneurial qualities are complemented by creativity and innovation, and in the mid-20th century, entrepreneurial research began to gain momentum, emphasizing a person-centred approach to predicting entrepreneurship based on psychological traits and human characteristics (Salilew, 2017; Fernandez \& Lanuza, 2015).

The current concept of entrepreneurship, similarly formulated in many sources, is well reflected in the OECD interpretation that the concept of entrepreneurship refers to proactive individuals who demonstrate their willingness to risk new or innovative ideas, create new products or services (Defining entrepreneurial activity..., n.d.).

Peculiarities of Entrepreneurship Measurement. Identifying the right indicators for entrepreneurship assessment is not easy. As can be seen from the information above, entrepreneurship is characterized by the concept of uncertainty, as it is a complex and dynamic activity that is often associated with various other business activities and economic outcomes. There are 2 approaches to entrepreneurship assessment in scientific sources - individual and economic entities.

Individual attitude. According to Landstrom and Benner (2010), over the past decade, much of the literature on entrepreneurship has focused on analyzing the approach that determines entrepreneurial behaviour, and many scholars (Gird \& Bagraim, 2008; Ismail, Jaffar \& Hooi, 2013; Fernandez \& Lanuza, 2015; Salilew, 2017; Pekkala Kerr et al., 2017) unanimously recognized that the traditional "personality traits approach" did not succeed in entrepreneurial research. According to Ismail et al. (2013), Theory of Planned Behaviour [TPB] became the most popular theoretical system used in entrepreneurship research. Robinson and Roberts (2010) agree that personal attitudes (planned behaviours) are a better approach to describing an entrepreneur rather than a person-oriented or demographic-oriented approach that has made up the majority of previous researches on individual entrepreneurship. According to the entrepreneurial literature, the attitudes approach is mainly based on TPB, according to which personal behaviour may be envisaged in the light of intentions, which in turn can be predicted on the basis of behaviour. Also, Sušanj, Jakopec, and Krečar (2015) noted that there is a correlation between a person's entrepreneurial characteristics, intentions, and behaviour. Therefore, some researchers (Chen \& Linan, 2009; Lorz, 2011) have studied the indirect impact of entrepreneurial characteristics on entrepreneurial intentions through an entrepreneurial approach. Properly capturing entrepreneurial abilities and inclinations that are comparable between individuals, not to mention comparisons in regions or states, is difficult, and entrepreneurial assessment tools from an individual perspective will always be partially misleading and criticized as empirical research is based on subjectivity and authority (the investigator represents the subject) that correlate with entrepreneurship.

Attitudes of economic entities. Due to the above-mentioned difficulties in individual research, a large part of entrepreneurship studies is based on an entity-wide approach that includes objective data on self-employment, business ownership, number of companies and density, etc. The main reason for this is the easy availability and comparability of these data in many countries and regions (OECD, 2015). However, shortcomings in the assessment of entrepreneurship from the point of view of economic entities are also not avoided. Although the data usually combine information from business registers, tax sources and company surveys prepared by local national statistical offices, and these data sources are generally of good quality, they are often provided and detailed enough to cover the full range of businesses, including the smallest ones, they do not (or rarely) take into account companies that work in the informal sector or engage in illegal activities (OECD, 2017; OECD, 2015).

Promoting entrepreneurship. Promoting youth entrepreneurship is becoming a growing policy interest in all OECD countries that Lithuania joined in 2018, becoming the 36th member (Verslo žinios, 2018). According to OECD data for 2017, studies conducted by the Local Economic and Employment Development Program confirm that it is precisely the local context that encourages the establishment and growth of start-ups and new companies. Creating and strengthening an entrepreneurial culture, which attracts and promotes talent, should, therefore, be a key component of the local youth entrepreneurship support system, with entrepreneurship education, initial support, and capacity building as key components to promote youth entrepreneurship (OECD, 2017). Efforts to develop the entrepreneurial potential of young people require different actions at the program and policy level. At the program level, design interventions are important, which are carefully targeted and tailored exclusively to the challenges and needs of young existing and potential enterprises who, like the youth themselves, are characterized by heterogeneity. In promoting youth entrepreneurship, it is important to link youth entrepreneurship programs with the results of impact assessments that allow assessing the effectiveness and pay-back of programs, having assessed, to invest in detailed programs, redistributing resources from inefficient programs (OECD, 2015). At the policy level, the emphasis is on the importance of integrated entrepreneurship education in formal education, as well as the growing importance of youth NGOs in promoting youth entrepreneurship. The sources mention the importance of formalization as a way to promote business development (Kiyani, 2017). Also, the "entrepreneurial spirit" of young people can be promoted through success stories and examples, and by simplifying administrative procedures (OECD, 2017). 
A review of scientific literature allows to distinguish these key theoretical aspects:

- There are many different definitions of entrepreneurship that correlate or conflict, causing some confusion and disagreement between scientists and specialists from different directions;

- Assessing entrepreneurship and its impact on development remains a challenge for many reasons, including different definitions of entrepreneurship, multiple nature and limited availability of comparable and reliable data;

- Promoting youth entrepreneurship in many countries has gained more attention in recent years as it is a way to promote employment, strengthen economic competitiveness and promote regional development;

- It has been established that there are internal and external barriers to entrepreneurship, the main ones being: entrance attitudes - institutional constraints (procedures) that affect business start-ups; financial constraints - young people are characterized by a lack of funding, difficulties in obtaining loans; entrepreneurial skills, which are determined by both personal education and experience or human capital.

\section{Research methodology}

Assessment of Entrepreneurial Intentions. In 2004, Professor Y. W. Chen and Professor F. Linan introduced Entrepreneurial Intention Questionnaire [EIQ], based on the integration of psychology and entrepreneurship literature, as well as empirical research in this field, to overcome the major shortcomings of previous research instruments (Chen \& Linan, 2009; Lorz, 2011). The model is based on I. Ajzen TPB, which can be adapted to almost all voluntary behavioural studies in a wide range of fields, including professional career choices. According to Ajzen's theory, intentions become the main explanation of behaviour (Ajzen, 2012). This shows the effort that a person would make to perform a particular action, in this case - entrepreneurial behaviour. EIQ includes 3 motivational factors (antecedents) that influence a person's intention:

- Personal approach [PA]. Specifies the degree to which an individual evaluates positively or negatively the possibility of being an entrepreneur. This includes not only the emotional ("I like", "I am attracted to") but also the evaluative aspect ("it has advantages");

- Subjective norms [SN]. It is a person's perceived social pressure to execute or not to execute the appropriate action (in the case of the research - entrepreneurial behaviour). Associated with the individual's environmental acceptance of his action;

- Perceived behavioural control [PBC]. This is the perception of ease or difficulty in becoming an entrepreneur. It is a similar concept to "self-efficacy", which is seen as the most significant and reliable indicator for predicting entrepreneurial behaviour. However, PBC includes not only the sense of being able, which is assessed by the self-efficacy indicator but also the perception of behavioural control.

-Entrepreneurship intentions [EI]. In the author's model, this element is referred to as the result of the above-mentioned 3 antecedents. In general, the authors in their study sought to assess how 3 antecedents correlate with entrepreneurial intentions, such as determining which of them has the greatest influence, but authors also assign a group of questions to entrepreneurial intentions. However, the authors also provided a block of questions for the assessment of this element (Chen \& Linan, 2009; Lorz, 2011).

The choice of the EIQ method for the study of entrepreneurial intentions was determined by the laconic and specific nature of the proposed questionnaire of the method, the fact that the authors responded to the weaknesses of previous entrepreneurial research when developing the method and that the wording of the questionnaire questions was quite simple and, as the authors themselves note, could be understood by respondents of all ages and education. The authors describing the methodology also claim that different levels of entrepreneurial knowledge can be expected to be reflected in the intentions of the individual. Thus, the responses of the respondents will allow at least preliminary conclusions to be drawn about the indirect influence of entrepreneurial characteristics (innate and acquired characteristics) and the formal/informal education of entrepreneurship (not) received by young people.

The part of the questionnaire evaluating entrepreneurial intentions consists of 4 areas -17 statements that the respondent has to evaluate in the 5-point Likert scale, where 1 - totally disagree; 5 - totally agree (subject areas: personal approach -5 statements; subjective norms -2 statements; perceived behaviour control -6 statements; entrepreneurial intentions -4 statements). When evaluating scaling data, the individual respondent's answers to all statements are summed up and the average is calculated. On an average basis, respondents to one of 3 levels of entrepreneurship (Figure 1).

One of the methods of analyzing the respondents' questionnaires - starting from their grouping into 3 groups. This allows us to analyze the responses of the young person with the appropriate level of entrepreneurship and to evaluate the level of relationship with other objects analyzed in the questionnaire - promotion of entrepreneurship, respondent's emigration attitudes, demographic characteristics. In this way, analyzing a large sample of respondents and data amounts, it is possible to conveniently check the relationships between the objects under investigation. Likewise, respondents' answers will provide valuable insights into which of the 4 domains is considered the weakest, allowing the investigator to consider suggestions on how these negative assessments can be improved in order to have a more positive meaning, indicating increased intentions of individual entrepreneurship. Linking individuals' 
entrepreneurship with demographic variables will show the potential existing relationships, trends (e.g., whether a person with higher education is more entrepreneurial, etc.), and will allow analyzing the level of youth entrepreneurship in each municipality.

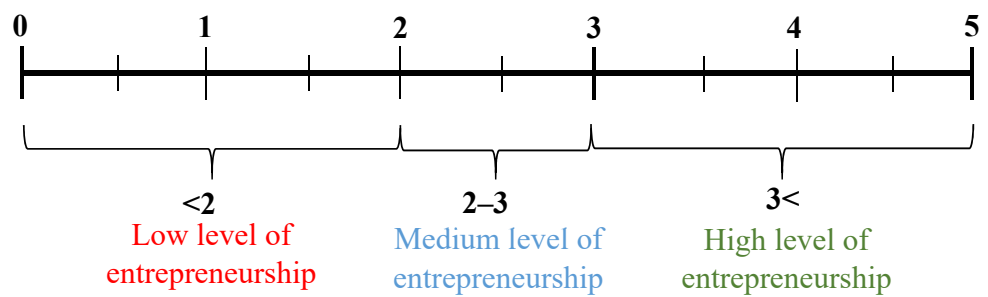

Figure 1. Entrepreneurship levels based on respondents' assessments (source: created by the authors based on Chen \& Linan, 2009)

Participation in Initiatives Promoting Entrepreneurship. Questionnaire related to the promotion of entrepreneurship was formed on the basis of 3 scientific articles (Chen \& Linan, 2009; Lorz, 2011; Muofhe \& Toit, 2011), the information of Department of Youth Affairs under the Ministry of Social Security and Labor [Department of Youth Affairs] and "Versli Lietuva". Questions are closed by type, with the ability to select multiple values or enter your own option. The answers received in this part of the study are not summed up, not divided into levels, etc., the answers received are meant to be related to the meanings of part I and III. In order to avoid overloading the questionnaire, this section contains 7 questions aimed at 1) Find out if a young person has been involved in entrepreneurship promotion activities (based on Lorz, 2011; Muofhe \& Toit, 2011); 2) Identify the most popular forms of entrepreneurship promotion activities (based on Lorz, 2011); 3) Learn about how young people appreciate their participation in these activities ("what did they give me?") (based on Muofhe \& Toit, 2011); 4) Determine if a young person has the intent to build a business, if not, for what reasons (based on Samuel et al. (2013), Chen \& Linan, 2009); 5) Find out about youth awareness about institutions in Lithuania that promote entrepreneurship promotion initiatives (based on "Versli Lietuva" information); 6) Find out about youth awareness about institutions involved in promoting entrepreneurship in a residential municipality (based on "Versli Lietuva" and Department of Youth Affairs).

Muofhe and Toit (2011) argued that there was a direct and indirect link between entrepreneurship promotion and entrepreneurial intentions. The indirect link occurs through the antecedents of entrepreneurial intentions mentioned in the model of Chen and Linan (2009), i.e., approach to entrepreneurship, social norms and perceived behavioural control. One of the links investigated by scientists is the link between promoting entrepreneurship and individual entrepreneurship. They found a weakly positive correlation of $0.430(p<0.01)$ although they interpreted it as moderately positive correlation and, based on this indicator, denied their hypothesis that there was no significant link between entrepreneurial motivation and entrepreneurial intentions. The entrepreneurship promotion construct is measured by 7 elements in order to find out the involvement of respondents in entrepreneurial activities and the evaluation of activities in which they were involved. Unfortunately, there is no example of a questionnaire in the public space, there are no detailed questions that have been asked to the respondents, so Muofhe and Toit (2011), gave more guidance, insights, and what direction should be given to issues.

Other researchers (Chen \& Linan, 2009; Lorz, 2011) investigated young people trying to find out what promotion measures are most effective in creating an environment favourable to youth entrepreneurship and what is the attitude of youth towards entrepreneurship based on entrepreneurship promotion initiatives in which they have been involved. In the questionnaire, respondents are asked questions to find out their awareness and interest in ongoing entrepreneurship programs. Researchers also studied other elements that are not relevant to the research of this work. The data of Department of Youth Affairs and "Versli Lietuva" allowed to distinguish the main institutions promoting youth entrepreneurship in Lithuania: "Versli Lietuva", "INVEGA", Employment Service - "Užimtumo tarnyba", municipalities, educational institutions, Youth NGOs, that are included in the questionnaire.

Emigration attitudes. The research part of the emigration attitudes is formed on the basis of researches of 2 scientific resources - van Dalen and Henkens (2008) - 5 questions, Nikolova and Graham (2015) - 3 questions, the whole block of emigration attitudes consists of 8 questions. According to van Dalen and Henkens (2008), emigration intentions and subsequent behaviour are assessed by a set of variables distributed over 4 groups: social networks; public domain; openness to new experiences; self-efficacy, that are presented below:

The impact of social networks is measured by dichotomous type questions. The importance of questions is based on the fact that the decision to migrate is often influenced by social networks. Social networking of friends and family abroad increases the likelihood of emigration. Social networks not only provide information about what a migrant can expect abroad but also offer "services" that reduce the cost of personal migration and integration.

Public domain consists of 15 statements that the respondent is asked to evaluate on a 5-point Likert scale where 1 is very positive; 5 - very negative. The importance of assessing this criterion is based on the fact that international 
migration is promoted not only by aspects of private life but also by satisfaction with public goody and their quality. This criterion assesses the opinion of respondents about the work of state institutions, satisfaction with the surrounding environment. It is believed that psychological characteristics predict whether a person will enter a new, unknown situation, as well as their emotional reactions to a new situation. Scientists distinguish two main personality traits, including 2 questions of the questionnaire:

- Openness to new experiences - the respondent is asked to evaluate his / her consent with 3 statements ( 1 totally disagree; 5 - totally agree). Higher susceptibility to new experiences/risks may have an impact on easier willingness to emigrate. The authors of the method claim that lovers of risk and new senses perceive the world as less threatening, so it is likely that the person is more prone to adventure and risk, the stronger his intention and the likelihood of his fulfilment.

- Self-efficacy - the respondent is asked to evaluate his / her consent with 3 statements ( 1 - totally disagree; 5 - totally agree). Self-efficacy means faith in your ability to deal with a particular situation effectively. According to the authors, this criterion predicts whether a person will get into a new or unfamiliar situation. Given that emigration is a new and uncertain experience, it is assumed that higher scores will be associated with stronger emigration intentions.

In their research, Nikolova and Graham (2015) tried to prove that social networks and the attitude to socioeconomic conditions are more important for emigration than income or dissatisfaction with life. The results of the study showed that the willingness to emigrate is related to social networks, dissatisfaction with the quality of work of institutions and individual circumstances (age and socio-demographic situation). Scientists have not developed a methodology for the sole purpose of investigating the intentions of emigration, asking 3 dichotomy-type questions for the assessment of entrepreneurial intentions and entrepreneurship plans, as stated, the overall "sum" of questions determines the solution of emigration. The main dependent variable is emigration intentions, which are assessed through a person's attitude to emigration "I appreciate it positively", "I prefer to leave", to verify credibility, a dependent variable - emigration plans based on the question of whether the respondents have specific emigration plans and whether they have them in the next 12 months.

As in the I part of entrepreneurship intentions, as well as in the third part of the emigration attitudes, the aim is to formulate the levels of emigration attitudes and assign them to young people according to the results of the research. The levels of emigration attitudes are calculated by summing up the values of dichotomic questions and Likert scales according to how the questions are coded in the SPSS program. By summing up the maximum values of all the questions, 112 is obtained, and the questions/statements that the respondents have to answer/evaluate are 26, thus dividing the resulting value by $4.31(112 / 26=4,307)$, which indicates the maximum emigration attitude level. As with entrepreneurial intentions, in the case of emigration attitudes, a scale is created with 3 levels (Figure 2).

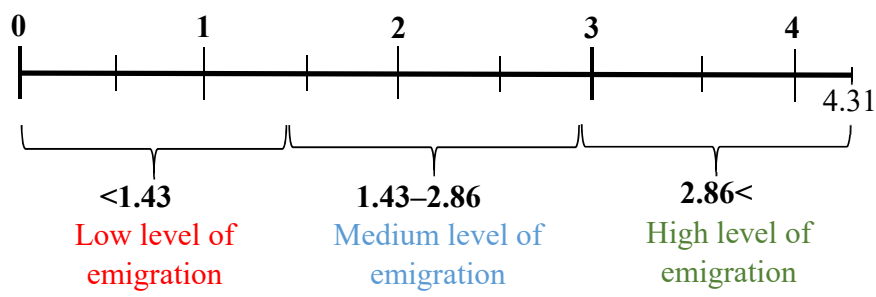

Figure 2. Levels of emigration attitudes based on respondents' assessments (source: created by the authors)

According to the scale shown in Figure 2, respondents are assigned a low, medium or high emigration probability level, which is judged from the above-mentioned areas of assessment, the higher overall significance of which indicates a higher probability of emigration.

Study sample. Young people aged 16-29, registered in the Employment Services subdivisions of Utena Region, who are unemployed. According to the data of the Employment Service, the average annual number of unemployed young people (16-29 years) in Utena county in 2018 was $1,220.7$. Thus, the general set consists of $\sim 1221$ youngsters, 301 young people $\left(\mathrm{n}=1 /\left(0.05^{2}+1 / 1221\right)\right.$ should be interviewed in the study to make this respondent survey representative and reliable with a tolerance of 5\%. For the test questionnaire, 41.86 per cent of the calculated sample was selected for testing.

Reliability of the research questionnaire. Having evaluated the reliability of the questionnaires, Cronbach's alpha coefficients are very high: the entrepreneurial share -0.918 , the emigration attitudes -0.783 . A well-compiled questionnaire should be evaluated at a coefficient of more than 0.7 , but is considered acceptable when the coefficient is more than 0.6 (Pukènas, 2009). Since the Cronbach alpha coefficients of the questionnaires in this study are significantly higher than the minimum coefficient indicated in the methodological guidelines, it can be said that among 
all the elements of the questionnaires there is a relatively high degree of consistency, therefore all the components of the questionnaires are evaluated as very reliable.

The course of the study. During the research, 150 questionnaires were distributed: 50 questionnaires for youth employment specialists of Molètai, Ignalina and Zarasai districts municipalities working in the employment service subdivisions and directly contacting young people aged 16-29. 132 questionnaires were received, of which 126 were suitable for further analysis of the study results.

Methods of analyzing study results. The data obtained from the questionnaires of young people aged 16-29 are processed and statistical analysis is performed using the statistical software package "SPSS 22" and "Excel". The data are coded, values are standardized, averages, percentages, correlations, statistical significance are calculated, the results are compared in the form of tables according to the selected attribute.

\section{Evaluation of entrepreneurship and emigration intentions}

Demographic characteristics of respondents. A similar proportion of male and female respondents, most of whom $(73.8 \%)$ were up to the age of 24, participated in the survey. Young people with basic, secondary and vocational education prevailed $-90.5 \%$, none of the respondents with a higher (master's degree) education participated in the survey. $9.5 \%$ of all respondents had higher education. Most of the questionnaires $-71.4 \%$ were received from the Employment Service of Molètai and Zarasai Districts Municipalities (see Table 1).

Table 1. Levels of respondents' entrepreneurial and emigration attitudes according to demographic characteristics (source: created by the authors)

\begin{tabular}{|c|c|c|c|c|}
\hline Characteristics & $\begin{array}{l}\text { Number of } \\
\text { respondents }\end{array}$ & $\begin{array}{l}\text { Percentage of } \\
\text { respondents }\end{array}$ & $\begin{array}{c}\text { Entrepreneurship } \\
\text { level } \\
\text { (MAX 5) }\end{array}$ & $\begin{array}{c}\text { Level of emigration } \\
\text { attitude } \\
\text { (MAX 4.31) }\end{array}$ \\
\hline \multicolumn{5}{|l|}{ Gender of respondents: } \\
\hline Female & 58 & $46 \%$ & 3.14 & 2.48 \\
\hline Male & 68 & $54 \%$ & 2.81 & 2.91 \\
\hline \multicolumn{5}{|l|}{ Age of respondents: } \\
\hline Up to 22 years old & 49 & $38.9 \%$ & 2.37 & 2.74 \\
\hline $22-24$ years old & 44 & $34.9 \%$ & 3.56 & 2.59 \\
\hline $25-29$ years old & 33 & $26.2 \%$ & 2.82 & 2.41 \\
\hline \multicolumn{5}{|l|}{ Education of respondents: } \\
\hline Basic & 18 & $14.3 \%$ & 2.44 & 2.42 \\
\hline Secondary & 38 & $30.2 \%$ & 2.72 & 2.44 \\
\hline Vocational & 58 & $46.0 \%$ & 2.94 & 2.78 \\
\hline Higher (college) & 9 & $7.1 \%$ & 3.32 & 2.97 \\
\hline Higher (Bachelor degree) & 3 & $2.4 \%$ & 3.49 & 3.48 \\
\hline Higher (Master degree) & 0 & 0 & - & - \\
\hline \multicolumn{5}{|c|}{ Residential municipality of residents } \\
\hline Molètai District Municipality & 49 & $38.9 \%$ & 3.08 & 2.92 \\
\hline Ignalina District Municipality & 36 & $28.5 \%$ & 2.68 & 2.57 \\
\hline Zarasai District Municipality & 41 & $32.5 \%$ & 2.82 & 2.63 \\
\hline
\end{tabular}

Levels of entrepreneurial and emigration intentions. The questionnaires received from respondents allowed to calculate the levels of entrepreneurship and emigration intentions, the values of which are presented in Table 1, according to demographic characteristics. The overall entrepreneurial level of all respondents is 2.97, and the level of emigration attitudes -2.70 . According to the scales of evaluation, entrepreneurship and emigration intentions are of a medium level, but the importance of entrepreneurship is not very far from the values of a high-level scale (3-5). In Table 1, respondents of several demographic characteristics are distinguished by a high level of entrepreneurship female respondents (10.5\% more entrepreneurial than men), respondents aged $22-24$ (33.4\% up to 22 years old; $20.8 \%$ more than 25-29 years old), respondents with higher college and university bachelor degree ( 20\% more than respondents with basic, secondary and vocational education) and the unemployed youth of Molètai District Municipality ( $\sim 13 \%$ more than those of Ignalina District Municipality and $8.4 \%$ more than youth of Zarasai District Municipality). It has been noted that young people with a higher university education are distinguished by high levels of emigration, young people with high college education and male respondents are not far behind. Such trends prevailing in the study can be analyzed more broadly to explain, for example: "Why do young people with higher education have a higher level of entrepreneurship and higher emigration attitudes?".

Entrepreneurship and emigration attitudes by participation in entrepreneurship promotion activities. Entrepreneurship and emigration levels can also be provided by whether individuals have been involved in entrepreneurship promotion initiatives, knowing whether the entrepreneurial and emigration intentions of individuals are different, depending on their participation in entrepreneurship promotion initiatives (Table 2). 49.2\% of 
respondents (62 respondents) have participated in entrepreneurship promotion activities, their entrepreneurial level is $16.9 \%$ higher than those of non-participants, and can be attributed to a high level of entrepreneurship on the scale of entrepreneurial levels. People with the above-mentioned level of entrepreneurship are also somewhat more inclined to emigrate $(9.5 \%)$, but the difference is not significant, implying that there is a significant trend.

Entrepreneurship and emigration attitudes according to the nature of entrepreneurship promotion activities. The levels of entrepreneurship and emigration can also be linked to the participation of young people in entrepreneurship promotion activities (see Table 2). Without a representative number of respondents, it is not possible to provide valid interpretations of the data received, but it is seen that the most popular forms of entrepreneurship promotion are seminars and various informative and other events. It can also be seen that young people participating in entrepreneurial activities organized informal education institutions have the highest level of entrepreneurship. Meetings with entrepreneurs are also associated with a higher level of entrepreneurship. It is worth mentioning that meetings with businessmen as well as various seminars and events can be organized in educational institutions, however, the survey questionnaire aims to find out how many young people have participated in programs and activities carried out exclusively in educational institutions and how many of them have participated in initiatives organized by other institutions, thus obtaining information on the extent to which young people are involved (included) in entrepreneurship promotion initiatives outside formal education institutions.

Table 2. Levels of respondents' entrepreneurship and emigration attitudes according to participation in entrepreneurship promotion activities and the nature of it (source: created by the authors)

\begin{tabular}{|c|c|c|}
\hline Characteristics & $\begin{array}{c}\text { Entrepreneurship } \\
\text { level } \\
\text { (MAX 5) } \\
\end{array}$ & $\begin{array}{l}\text { Level of emigration attitude } \\
\text { (MAX 4,31) }\end{array}$ \\
\hline \multicolumn{3}{|c|}{ Participation in entrepreneurship promotion activities } \\
\hline I have participated & 3.24 & 2.74 \\
\hline I have not participated & 2.69 & 2.48 \\
\hline \multicolumn{3}{|l|}{ Entrepreneurship promotion activities: } \\
\hline Seminars, events $(58.2 \%)$ & 3.12 & 2.72 \\
\hline Free consultations $(21.4 \%)$ & 2.94 & 2.41 \\
\hline Meetings with entrepreneurs $(26.9 \%)$ & 3.14 & 2.17 \\
\hline Classes in formal education institutions (39.01\%) & 3.31 & 2.26 \\
\hline
\end{tabular}

Calculation of correlation coefficients. Table 3 shows that no statistically significant relationship between entrepreneurship and emigration has been identified $(p>0.05)$. However, the levels of entrepreneurship and emigration attitudes (Table 1) indicate that there is a tendency among individual youth groups (e.g., according to demographic characteristics) to have a higher level of emigration attitudes in the case of higher entrepreneurship (e.g., it has been noted that young people with university education have the highest entrepreneurial and emigration attitudes). Thus, in the absence of a representative sample survey, and without analyzing the links between the different elements, no precise conclusions can be drawn as to whether a link exists, and if exists, or generally exists, on the basis of the responses of all respondents, or only exists in a youth group with specific characteristics.

Table 3. Correlation calculations (source: created by the authors)

\begin{tabular}{|l|c|c|}
\hline \multicolumn{1}{|c|}{ Variables } & $\begin{array}{c}\text { Correlation } \\
\text { coefficient }(\mathrm{r})\end{array}$ & $\begin{array}{c}\text { Significance level } \\
(\mathrm{p})\end{array}$ \\
\hline Entrepreneurship and emigration attitudes & $(0.037)$ & 0.898 \\
\hline $\begin{array}{l}\text { Emigration attitudes and participation in entrepreneurship promotion } \\
\text { initiatives }\end{array}$ & 0.134 & 0.532 \\
\hline Participation in entrepreneurship promotion initiatives and entrepreneurship & 0.298 & 0.314 \\
\hline
\end{tabular}

Table 3 shows that no statistically significant relationship between participation in entrepreneurship promotion activities and emigration attitudes was found $(p>0.05)$. The results can be interpreted in a similar way to the previous correlation calculation. The entrepreneurial level (see Table 4) shows that young people participating in entrepreneurial initiatives have a $16.9 \%$ higher entrepreneurial level than non-entrepreneurs. Differences in emigration attitudes between different groups of young people are small, insignificant.

Table 3 shows how youth entrepreneurship correlates with participation in entrepreneurship promotion initiatives. There is no statistically significant link between entrepreneurship promotion initiatives and entrepreneurship $(p>0.05)$, but the level of entrepreneurship shows that a higher level is associated with a youngster's involvement in entrepreneurship promotion initiatives (Table 2).

Thus, empirical research allowed to evaluate the levels of entrepreneurial and emigration attitudes of young people with different demographic characteristics and to find out the tendencies of youth participation in entrepreneurship promotion initiatives. It has been observed that the comparison of results by levels showed more 
striking relationships than the correlation calculations. Although a method test made it possible to verify its suitability, a more representative sample of respondents is needed to provide valid results.

\section{Conclusions}

The results of the study did not show the correlation between the analyzed elements - youth entrepreneurship, participation in entrepreneurship promotion initiatives and emigration attitudes, however, the results of the research are not sufficient when interviewing $\sim 41.86 \%$ (126 respondents) of the required sample ( $100 \%-301$ young people), to present representative conclusions about the research relationships.

The research carried out has made it possible to ascertain the appropriateness of the research methodology for assessing youth entrepreneurship and emigration attitudes. Both methods (entrepreneurship and emigration attitudes) are based on previous research by scientists, have been tested and described quite broadly, providing additional information to enrich the interpretation of the results of the study.

From a theoretical point of view, this study contributed to the existing research on entrepreneurship, supplementing it with new insights on the existence of a relation between entrepreneurship promotion, entrepreneurship, and the tendency to emigrate, which, as far as the authors are aware, was researched neither in Lithuania nor globally. The research methodology clarified ways to evaluate youth entrepreneurship and position on emigration, it also presented a potential evaluation questionnaire for youth involvement in entrepreneurship promotion activities.

The methodology of the conducted research consists of the assessment of 3 elements that can be evaluated individually, and also by combining them and calculating relations, and adapting the evaluation methodology of each of these elements to the research of other nature, such as the evaluation of the relation between person's position on emigration and another element chosen by the author, in order to obtain information about the relation existing between the elements. It should be noted that the development of the methodology for this research may be useful not only in the context of the current Lithuanian issues. This methodology is useful insofar as it helps to better understand the similarities and differences of general global trends and processes taking place in Lithuania, in the fields of youth entrepreneurship, position on emigration, and entrepreneurship promotion.

From a practical point of view, the calculation of entrepreneurial levels presented in the methodology may be useful for the assessment of youth entrepreneurship, observation of progress or changes, at the scale of different territorial units. This calculation can also be adapted for the assessment of the changes in youth entrepreneurship before and after participation in entrepreneurship promotion initiatives, thus judging about the appropriateness of implemented initiatives. The section on the assessment of the position on emigration has a high-reliability indicator and can also be employed in the research of various target groups, judging about the potential scale of emigration. Such research is particularly relevant for countries where the population emigration problem is particularly sensitive. Knowledge of connection would also help to understand whether manipulating youth entrepreneurship through entrepreneurship promotion initiatives can influence emigration. This issue is relevant to countries facing an emigration problem and seeking to develop effective measures to reduce emigration.

All three parts of the research can be integrated together or applied separately in order to obtain information on the relevant field - the entrepreneurial intentions of individuals, the engagement of individuals in the entrepreneurial promotion activities implemented at the local level and satisfaction that these activities provide, as well as the personal position on emigration. It should be noted that the part on the entrepreneurship promotion should be adapted with respect to a different country, region, municipality or other territorial units, by linking it to the peculiarities of entrepreneurship promotion of the researched territory.

The main restriction of this study is the relatively small sample of respondents for valid conclusions about the relation between entrepreneurship promotion, entrepreneurship, and position on emigration. Since no large-scale research has been conducted, it is difficult to identify the weaknesses of the developed methodology and suggest improvements. Secondly, the research presented in this paper was performed on the basis of on a single country and its single region, thus the results of the assessment of the relation between youth entrepreneurship and position on emigration, will not necessarily apply to other geographic areas. It is likely that it will be characteristic only to countries with similar economic, social, and cultural development. Therefore, it is not possible to evaluate the research findings at the scale of the international context. Thirdly, the information gathered during the research reflects only a small fraction of the opinion of youth registered in the Employment Services of analyzed municipalities. As the economic and demographic situation changes and other external factors become active, the youth assessment, especially in the fields of position on emigration and entrepreneurship, may change. Thus, it is not possible to draw general conclusions about the presence or absence of the relation, and the extent of the involvement of the youth of Utena region in entrepreneurship promotion initiatives, the level of entrepreneurship, and the position on emigration.

Future scientific research may relate to the performance of the research in other regions that have different cultural, social, economic, geographic, political, and other parameters than those that are characteristic to Lithuania or analyzed region. Such further studies would allow presenting valid conclusions about the (non)existence of a connection based on international (multicultural) studies. Research could also be conducted between people of different 
social status, based on the presence/absence of the differences that exist between them. Such information is useful for national and local policymakers when monitoring trends (emigration and/or entrepreneurship intentions) and planning response measures.

\section{References}

Aidis, R., \& Krupickaitè, D. (2007). Jaunimo emigracijos tyrimas: Lietuvos universitetinių aukštujų mokyklų studentų nuostatos emigruoti [Study of youth emigration: emigration of students of Lithuanian university higher education institutions]. In Lietuviu migracijos ir diasporos studijos. Retrieved from https://eltalpykla.vdu.lt/bitstream/handle/1/33274/ISSN23516461_2007_N_3.PG_36-50.pdf?sequence=1\&isAllowed=y

Ajzen, I. (2012). The theory of planned behaviour. In Handbook of theories of social psychology. Sage Publishing. https://doi.org/10.4135/9781446249215.n22

Atkočiūnienè, V., \& Navasaitienè, S. (2013). Kaimo bendruomeniu vaidmuo skatinant jaunimo versluma [Role of rural communities in promoting youth entrepreneurship]. Aleksandras Stulginskis University, Kaunas, Lithuania. Retrieved from https://vb.asu.lt/object/elaba:6090688/

Bakina, A. V., Yaremtchuk, S. V., Orlova, O. A., \& Krasnoperova, Y. V. (2019). Life satisfaction and migration intention of youth. Advances in Economics, Business and Management Research. https://doi.org/10.2991/iscfec-18.2019.158

Bastianon, C. D. (2019). Youth migration aspirations in Georgia and Moldova. Migration Letters, 16(1), $105-121$. https://doi.org/10.33182/ml.v16i1.596

Boateng, O. G., Boateng, A. A., \& Bampoe, S. H. (2014). Barriers to youthful entrepreneurship in rural areas of Ghana. Global Journal of Business Research, 8(3), 109-119.

Braguinsky, S., \& Klepper, S. (2009). Schumpeterian entrepreneurship. Atsushi Ohyama, University of Illinois, UrbanaChampaign. Retrieved from https://economicdynamics.org/meetpapers/2009/paper_772.pdf. https://doi.org/10. 2139/ssrn. 1347063

Brown, C., \& Thornton, M. (2013). How entrepreneurship theory created economics. Quarterly Journal of Austrian Economics, 16(4), 401-420. Retrieved from https://mises.org/library/how-entrepreneurship-theory-created-economics

Chandra, Y. (2018). Mapping the evolution of entrepreneurship as a field of research (1990-2013): A scientometric analysis. Department of Public Policy, City University of Hong Kong, Hong Kong SAR, China. https://doi.org/10.1371/journal.pone.0190228

Chen, W. Y., \& Linan, F. (2009). Development and cross-cultural application of a specific instrument to measure entrepreneurial intentions. Entrepreneurship: Theory and Practise, 33(3), 593-617. https://doi.org/10.1111/j.1540-6520.2009.00318.x

Chuvashov, S. (2014). Socio-psychological capital, values and emigration intentions of Russian youth (Higher School of Economics Research Paper No. WP BRP 23/PSY/2014). https://doi.org/10.2139/ssrn.2526699

Čiburienė, J., \& Guščinskienė, J. (2009). Jaunimo verslumas: lyčių aspektas [Youth entrepreneurship: gender aspects]. Ekonomika ir vadyba: aktualijos ir perspektyvos, 1(14), 62-69. Retrieved from https:/epubl.ktu.edu/object/elaba:6082824/

Dako-Gyeke, M. (2016). Exploring the migration intentions of Ghanaian youth: a qualitative study. Journal of International Migration and Integration, 17(3), 723-744. https://doi.org/10.1007/s12134-015-0435-z

Defining entrepreneurial activity: definitions supporting frameworks for data collection. (n.d.) Retrieved from https://www.oecd.org/sdd/business-stats/39651330.pdf

Di Nunzio, M. (2015). What is the alternative? Youth, entrepreneurship and the developmental state in Urban Ethiopia. International Institute of Social Studies, 46(5), 1179-1200. https://doi.org/10.1111/dech.12187

Dibeh, G., Fakih, A., \& Marrouch, W. (2018). Decision to emigrate amongst the youth in Lebanon. International Migration, 56(1), 5-22. https://doi.org/10.1111/imig. 12347

Ekonomikos terminų žodynas [Dictionary of economic terms]. (n.d.). Retrieved from https://zodynas.vz.lt/Verslumas

European Commission. (n.d.). Promoting entrepreneurship. Retrieved from https://ec.europa.eu/growth/smes/promotingentrepreneurship_lt

Falck, O., Gold, R., \& Heblich, S. (2017). Lifting the iron curtain: school-age education and entrepreneurial intentions. Journal of Economic Geography, 17(5), 1111-1148. https://doi.org/10.1093/jeg/lbw026

Fernandez, P., \& Lanuza, I. M. (2015). Entrepreneurship, togetherness, and emotions: a look at (postcrisis?) Spain. Journal of Management Inquiry, 24(4), 424-428. https://doi.org/10.1177/1056492615579786

Ferreira, J. J. M., Finisterra do Paco, A. M., Raposo, M., Rodrigues, R. G., \& Dinis, A. (2011). Entrepreneurial intention among secondary students: Findings from Portugal. International Journal of Entrepreneurship and Small Business, 13(1), 92-106. https://doi.org/10.1504/IJESB.2011.040418

Gird, A., \& Bagraim, J. J. (2008). Predicting the entrepreneurial intentions of planned behaviour in Zambia, Africa. South African Journal of Psychology, 38, 711-724. https://doi.org/10.1177/008124630803800410

Global Entrepreneurship Monitor. (2012). 2012 Global Report. Retrieved from https://www.gemconsortium.org/report/48545

Herz, A., Diaz-Chorne, L., Diaz-Catalan, C., Altissimo, A., \& Carignani, S. S. (2019). Are you mobile, too? The role played by social networks in the intention to move abroad among youth in Europe. Migration Letters, 16(1). https://doi.org/10.33182/ml.v16i1.622

Innovation and Entrepreneurship. (n.d.). Retrieved from https://www.butler-bowdon.com/peter-drucker---innovation-andentrepreneurship.html

Ismail, N., Jaffar, N., \& Hooi, T. S. (2013). Using EAO model to predict the self-employment intentions among the Universities' undergraduates in Malaysia. International Journal of Trade, Economics and Finance, 4(5), $282-287$. https://doi.org/10.7763/IJTEF.2013.V4.302

Kiyani, S. A. (2017). Role of entrepreneurship education on student attitudes. Abasyn Journal of Social Sciences, 10(2), $270-293$. Retrieved from https://ajss.abasyn.edu.pk/admineditor/papers/V10I2-4.pdf 
Landstrom, H., \& Benner, M. (2010). Entrepreneurship research: A history of scholarly migration. Lund University, Lund, Sweden. Retrieved from https://www.researchgate.net/publication/270820249_Entrepreneurship_research_A_history_of_ scholarly_migration

Lithuanian Department of Statistics. Tarptautine migracija [International migration]. (n.d.). Retrieved from https://osp.stat.gov.lt/statistiniu-rodikliu-analize?hash=bbf4277f-f4da-4ac4-baa6-9407f23935f5\#/

Lorz, M. (2011). The impact of entrepreneurship education on entrepreneurial intention (Doctoral Dissertation). The University of St. Gallen, School of Management, Economics, Law, Social Sciences and International Affairs, Germany. Retrieved from https://www1.unisg.ch/www/edis.nsf/SysLkpByIdentifier/3966/\$FILE/dis3966.pdf

Merkys, G., Baršauskienė, V., \& Antienè, D. (2006). Lietuvos studentų emigracinès nuostatos ir jas lemiantys veiksniai [Emigration intentions of Lithuanian students and their determinants]. Baltic Journal of Sport and Health Sciences, 3(62), $36-42$.

Mokslo ir studijų stebėsenos ir analizės centras [MOSTA]. (n.d.). Išspręsti darbo jégos problemas turime dešimtmetị [We have a decade to deal with labor problems]. Retrieved from https://www.mosta.lt/lt/naujienos/8-naujienos/456-isspr-sti-darbojegos-problemas-turime-desimtmeti

Muofhe, J. N., \& Toit, W. F. (2011). Entrepreneurial education's and entrepreneurial role models' influence on career choice. University of Johannesburg, Johannesburg, South Africa. SA Journal of Human Resource Management/SA, 9(1), 1-15. https://doi.org/10.4102/sajhrm.v9i1.345

Ngorora, G. P. K., \& Mago, S. (2013). Challenges of rural entrepreneurship in South Africa: Insights from Nkonkobe municipal area in the Eastern Cape province. International Journal of Information Technology and Business Management, 16(1), 111.

Nikolova, M., \& Graham, C. (2015). Well-being and emigration intentions: new evidence from the gallup world poll. The University of Maryland, College Park IZA, Maryland, United States. Retrieved from https://conference.iza.org/ conference_files/transatlantic_2015/nikolova_m9715.pdf

OECD. (2015). Entrepreneurship at a Glance 2015. Retrieved from https://www.oecd-ilibrary.org/industry-andservices/entrepreneurship-at-a-glance-2015_entrepreneur_aag-2015-en

OECD. (2017). Entrepreneurship at a Glance 20177. Retrieved from https://read.oecd-ilibrary.org/employment/entrepreneurshipat-a-glance-2017_entrepreneur_aag-2017-en\#page1

Pekkala Kerr, S., Kerr, W. R., \& Xu, T. (2017). Personality traits of entrepreneurs: a review of recent literature (Working Paper No. 18-047). Harvard Business School. Retrieved from https://www.hbs.edu/faculty/Publication\%20Files/18047 b0074a64-5428-479b-8c83-16f2a0e97eb6.pdf. https://doi.org/10.3386/w24097

Pocius, A., \& Burneika, D. (2017). Padèties darbo rinkoje skirtumai Lietuvos regionuose [Differences in labor market situation in Lithuanian regions]. Lietuvos socialiniu tyrimu centras, 56(1), 18-30. Retrieved from https://www.statisticsjournal.lt/ index.php/statisticsjournal/article/download/178/pdf

Pukènas, K. (2009). Kokybiniu duomenu analize SPSS programa [Qualitative data analysis SPSS program]. Lithuanian Academy of Physical Education, Kaunas, Lithuania. Retrieved from https://www.spssanalize.lt/wp-content/uploads/2014/03/ kokybiniu_duomenu_analize_SPSS_programa.pdf

Regele, M. D., \& Neck, H. M. (2012). The entrepreneurship education subecosystem in the united states: opportunities to increase entrepreneurial activity. Journal of Business and Entrepreneurship, 23(2), 1-25.

Robinson, B., \& Roberts, L. P. (2010). Home-based entrepreneurs, commercial entrepreneurs and white-collar workers: a comparative study of attitudes toward self-esteem, personal control and business growth. Journal of Small Business \& Entrepreneurship, 23(3), 333-353. https://doi.org/10.1080/08276331.2010.10593489

Roman, M., \& Vasilescu, M. D. (2016). Explaining the migration intentions of Romanian youth: are teenagers different? The Journal of National Institute of Statistics: Romanian Statistical Review, 4, 69-86. Retrieved from https://www.insse.ro/cms/sites/default/files/field/publicatii/revista_romana_de_statistica_nr4_2016.pdf\#page $=69$

Salamonska, J., \& Czeranowska, O. (2018). Janus-faced mobilities: motivations for migration among European youth in times of crisis. Journal of Youth Studies (in press). https://doi.org/10.1080/13676261.2019.1569215

Salilew, G. F. (2017). Assessing entrepreneurial attitude orientations of graduating students at university of gondar. European Journal of Business and Management, 9(22), 13-23.

Samuel, Y., A., Ernest, K., \& Awuah, B., J. (2013). An assessment of entrepreneurship intention among sunyani polytechnic marketing students. International Review of Management and Marketing, 3(1), 37-49.

Saulenas, D. (2007). Kaimo jaunimo verslumo skatinimas [Promotion of rural youth entrepreneurship]. Lithuanian University of Agriculture, Kaunas, Lithuania. Retrieved from https://jaunasis-mokslininkas.asu.lt/smk_2007/kaimo_pletra/ Saulenas_Donatas.pdf

Skačkauskaite, A. (2007). Tarptautinè lietuvių migracija: studentų nuostatos, požiūris ir emigracinių galimybių vertinimas [International Lithuanian migration: students attitudes, approach and assessment of emigration opportunities]. In Lietuviu migracijos ir diasporos studijos. Retrieved from https://eltalpykla.vdu.lt/bitstream/handle/1/33273/ISSN23516461_2007_N_3.PG_51-60.pdf?sequence=1\&isAllowed=y

Sušanj, Z., Jakopec, A., \& Krečar, I. M. (2015). Verifying the model of predicticting entrepreneurial intention among srudents of business and non-business orientation. Management, 20(2), 49-69.

Tiškutè, A., \& Sondaitė, J. (2011). Kokybinè studentų ketinimo emigruoti arba planuoti savo ateiti Lietuvoje socialinių ar psichologinių veiksnių analizè [Qualitative analysis of students' intention to emigrate or plan their future in Lithuania social or psychological factors]. Socialinis darbas, 10(2), 365-376. Retrieved from https://repository.mruni.eu/handle/007/11622

Traikova, D., Mollers, J., \& Petrick, M. (2018). Go west? Emigration intentions of young Bulgarian agricultural specialists. Journal of Rural Studies, 62, 134-145. https://doi.org/10.1016/j.jrurstud.2018.07.008

Užimtumo tarnyba. (n.d.). Statistiniai rodikliai [Statistical indicators]. Retrieved from https://uzt.lt/darbo-rinka/statistiniairodikliai/ 
Petronyte, A.; Ulbinaite, A. 2019. Evaluation of the relationship between youth entrepreneurship and emigration intentions: theoretical-methodological aspects

van Dalen, P. H., \& Henkens, K. (2008). Emigration intentions: mere words or true plans? Explaining international migration intentions and behavior. Tilburg University, Tilburg, Netherlands. https://doi.org/10.2139/ssrn.1153985

van Mol, C. (2016). Migration aspirations of European youth in times of crisis. Journal of Youth Studies, 19(10), 1303-1320. https://doi.org/10.1080/13676261.2016.1166192

Verslo žinios. (2018). Lietuva pakviesta tapti 38-aja EBPO nare [Lithuania is invited to become the 38th OECD member]. Retrieved from https://www.vz.lt/verslo-aplinka/2018/05/03/lietuva-bus-pakviesta-tapti-36-aja-ebpo-nare

Wiger, N. P., Chapman, D., W., Baxter, A., \& DeJaeghere, J. (2015). Context matters: A model of the factors associated with the effectiveness of youth entrepreneurship training. Springer Netherlands, 45(4), 533-547. https://doi.org/10.1007/s11125-015-9366-x

Župerka, A., \& Župerkienè, E. (2014). Studentų verslumo ugdymo tyrimas vakaru Lietuvos regione [Study of the student entrepreneurship education in Western Lithuania region]. Regional Formation and Development Studies, 1(6), 195-208. Retrieved from https://journals.ku.lt/index.php/RFDS/article/viewFile/547/436 